\title{
Factors of Land-Use Change, Case Study: In Kota Juang, Bireuen, Indonesia
}

\author{
A.Munandar ${ }^{1 *}$, A.Marisa ${ }^{2 * *}$, H.Tamiami Fachrudin ${ }^{2 * * *}$ \\ \{*aris.arsitektur@gmail.com,**amy@usu.ac.id,*** hilma@usu.ac.id \} \\ Student of Master Degree Program of Architecture Department, Faculty of Engineering,Universitas \\ Sumatera Utara ${ }^{1}$ \\ Lecturer of Master Degree Program of Architecture Department, Faculty of Engineering,Universitas \\ Sumatera Utara ${ }^{2}$
}

\begin{abstract}
The land-use in the city can change after a period of time. because of the growing demand for a land. The land-use of Kota Juang began to change in the year of 2001. This case occurs because of the influence of several factors such as urban expansion, topography, accesibility and human growth. This research aims to identify the influence of those factors to the land-use. This study used qualitative method by using descriptive analysis to analyze the impact of the urban expansion, topography, accesibility and human growth to the land-use change in Kota Juang, Bireuen. The results of this study suggest that, in 1990-2000 the land-use of Kota Juang was more dominant for agriculture area, but after the urban expasion in 2000-2017 most of the land in Kota Juang is used for the residential, commercial, government, and public area. The agriculture area in Kota Juang has been reduced up to $33,8 \%$. This study can benefit the community, developers and others in the industry to obtain information on the land-use changes that occur in Kota Juang. The findings can also be used by the government in evaluating the spatial plans in Kota Juang, Bireuen.
\end{abstract}

Keywords: Accessibility, human growth, land-use, topography, urban expansion.

\section{Introduction}

The increasing demand for a land continues so indirectly there are some factors that causes the landuse change, such as agricultural land which turns into a residential area, due to the process of developing the suburban area and lack of control in using space [1]. This case is considered reasonable to create a city which has more benefit, but the land-use change should be more structured and regulated to minimize future land problems. The wrong allocation of land-use will result in a bad image of the city [2].

Kota Juang is the capital of Bireuen Regency and the physical development of this city grows more rapidly, this is because the high demand of facilities and infrastructure to provide the traffic service to meet the needs of intensive care treatment at the urban. Most land-use change in Kota Juang is agriculture, changed to develop the city, acording to spatial planning development (RTRW) agriculture area located in core Kota Juang has been change to commercials area, housing and other use. The change urban land-use in Kota Juang are resonable due to this city born in 2005 as capital of Bireuen regency and 1999 Bireuen government start to independet region segregation from Aceh Utara. The population density of Kota Juang is 50.070 people and the urban area is 3.156 ha [3]. 
Land-use change is an increase in land-use from one side of use to another, followed by a reduction in the type of land-use from one time to the next, or changing the function of a land at different times [2-5] The change of land-use in a city can be influenced by several factors including topography, accessibility, population growth and urban expansion [3][6].

The urban expansion is experiencing administrative expansion or formation new urban region, it case caused human factors and urban develompment to terms of government development efforts and urban public facilities [7]. Conditon topography also affect to change land-use caused be a separator land-used area, such as housing area with agriculture area. Good land to be developed as a residential area is a relatively sloping land, has a small slope, so it has great development potential. Bulding mass destiny determine ideally conditions of topography and natural landscape.

Accessibility is the interaction of activities with the transportation system to access public facilities, accessibility is often associated with distance, time acces and costs. Good accessibility is expected to overcome some mobility barriers, both related to physical mobility, for example accessing highways, shops, office buildings, schools, cultural centers, industrial and recreational locations [8].

Population growth factors cause opportunities available work along with the development of a city causes the increasing population of the city. As whole, the urban development and changes of land-use is growing dynamically and naturally influed by human, human needs for shelter, human potential, financial, socio-cultural and technological.

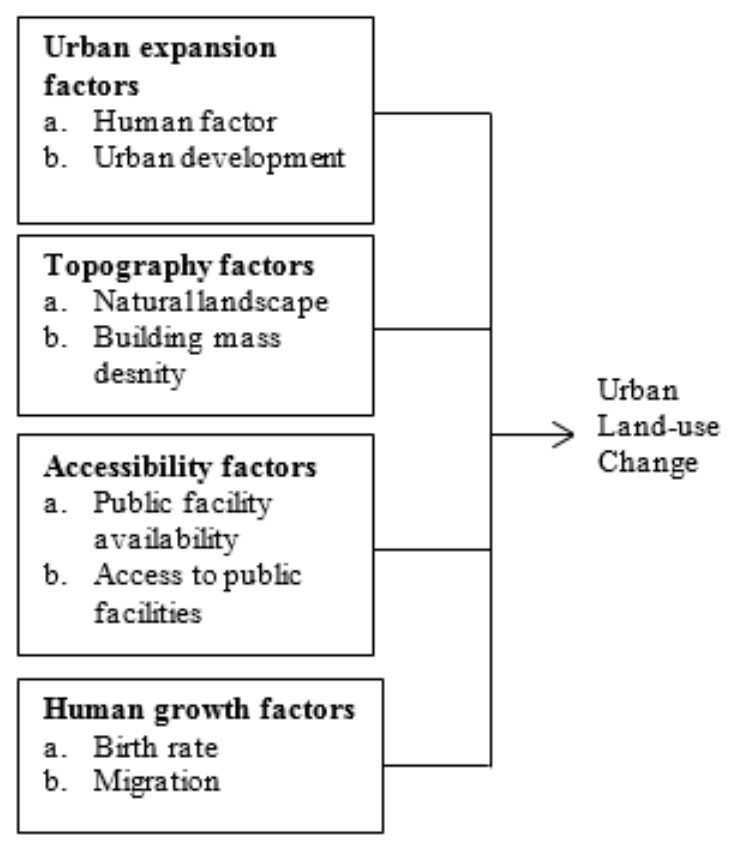

Fig.1. Literature review

Overall based on theoretical studies of these four factors, it will later be analyzed to find out which factors most change land-use.. 


\section{Methodology}

\subsection{Research Area}

This study is located in Kota Juang, Bireuen, on the Sumatera cross highway this city is a transit of trade region aceh because it is at the midpoint of the Aceh economy and easily achieved by other regions. The geographic of Kota Juang, Bireuen has an area 3.156 Ha with 23 villages and population 50710 people (BPS Bireuen). Kota Juang is a sub-distrik in Bireuen Regency and segregation from Jeumpa sub-distrik in 2005 this urban located in core Bireuen as serve of other sub-distrik area such as the activity existence of government, commercial and public services for all sub-distik region in Bireuen.

Acording to the government spatial plant (RDTR) only 21 village located in the core urban Kota Juang, Bireuen so that is the study area with boundary arean north with Kuala sub-distrik, south with Juli sub-distrik, east with Peusangan sub-distrik and west with Jeumpa sub-distrik. The map of study area is show in Figure 2.

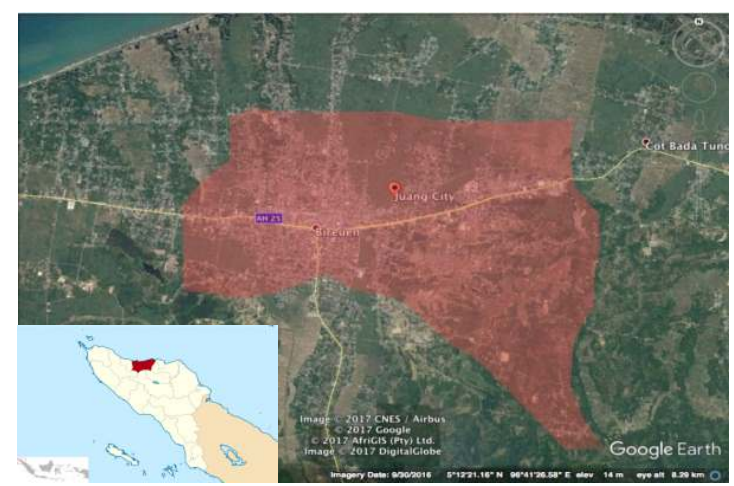

Fig. 2. Photography satelite Kota Juang

Kota Juang having special character landscape his position transition hill to the beach, and condition of counture moore flat. Other benefits in this city are located national roads, that is westward connection to Banda Aceh, eastward to Medan and southward to Takengon.

\subsection{The Method}

This study used qualitative method by using observation as the technique for data collection. Observations is see the field situation and recording all observational data. This method aims to find out the truth or facts in the field [8]. This study used descriptive analysis to analyze the influence of factors urban expansion, topography, accecibility and human growth population to the land-use change in Kota Juang, Bireuen.

Data analysis in this research starts at at the beginning of data collection until data collection is complete. This study also uses maps land-use maps from the development planning agency (Bappeda) of Bireuen identify the changes of land-use in Kota Juang, Bireuen. 


\section{Result and Discussion}

\subsection{Urban Expansion Factor}

In period 1990-2000 Kota Juang is sub disrik of Jeumpa under Aceh Utara goverment, this land-use before formation Bireuen Regency dominant of land-use agriculture compared other land-use, the details of period before urban expansion are commercial $130.51 \mathrm{Ha}(4.6 \%)$, housing $935.83 \mathrm{Ha}(33.20 \%)$, agriculture $1638 \mathrm{Ha}(58.12 \%)$, government $8.11 \mathrm{Ha}(0.28 \%)$, public facility $31.6 \mathrm{Ha}(1.12 \%)$, open space $21.4 \mathrm{Ha}(0.75 \%)$, mix used (commercial and housing) $20.91 \mathrm{Ha}(0.74 \%)$, industry $4.31 \mathrm{Ha}(0.15 \%)$, military area $6.06 \mathrm{Ha}(0.2 \%)$ and lake reservoir $21.29 \mathrm{ha}(0.75 \%)$. for more details can be seen in Figure 3.

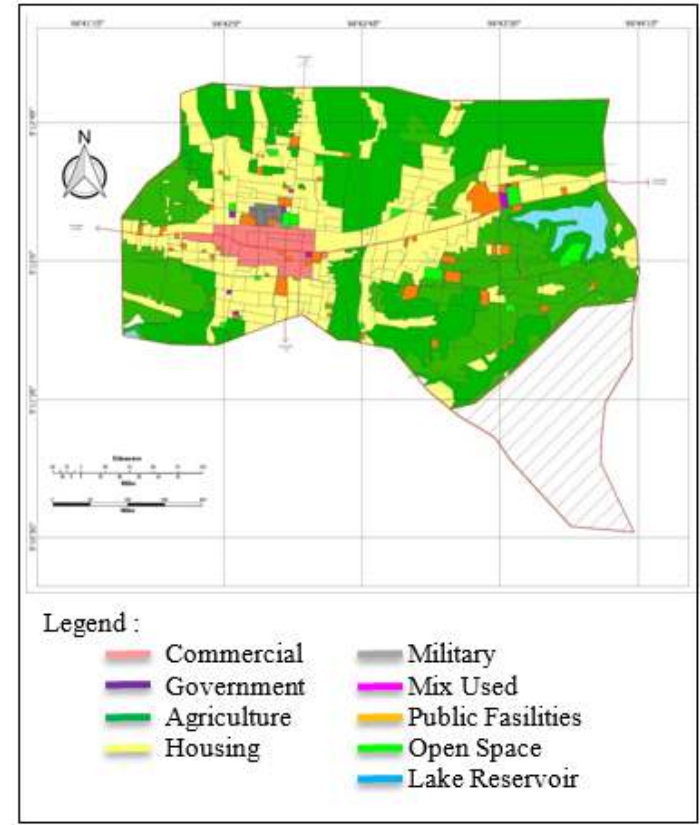

Fig. 3. Land-use Kota juang in 1990-2000

Basically land-use in this period was caused by the lack of community activities and the economic activities of the area still held by city of Lhokseumawe which has its own power in the capital Aceh Utara. But as time goes the city of Bireuen born as a developing satelite city and Kota Juang sub-sistrik as capital. In Figure 3 above it appears dominant green means the amount of agricultural land-use is very large before urban expansion occurs.

During 2001-2017 Bireuen start to independent regency it mean out of Aceh Utara government, so this period many land-use change to develop new government area, public facilities and other needs of Bireuen government, Kota Juang has experiencing these changes caused city of capital and core of the city.

The land-use significant change is reduced agriculture and housing goes to widened, based analysist agriculture $24,7 \%$ and land-use housing be $52.57 \%$ and commercial $13.6 \%$. The detail wide land-use commersial $383.16 \mathrm{Ha}(13.6 \%)$, housing $1481.68 \mathrm{Ha}(52.57 \%)$, agriculture $684 \mathrm{Ha}(24.27 \%)$, goverment $25.53 \mathrm{Ha}(0.90 \%)$, public fasility $45.6 \mathrm{Ha}(1.61 \%)$, open space $21.4 \mathrm{Ha}(0.75 \%)$, mix used (commercial and housing) $141.12 \mathrm{Ha}(5.05 \%)$, industry 
11.64Ha $(0.41 \%)$, military area $6.06 \mathrm{Ha}(0.2 \%)$ and lake reservoir $21.29 \mathrm{ha}(0.75 \%)$. Detail map of land-use in Figure 4.

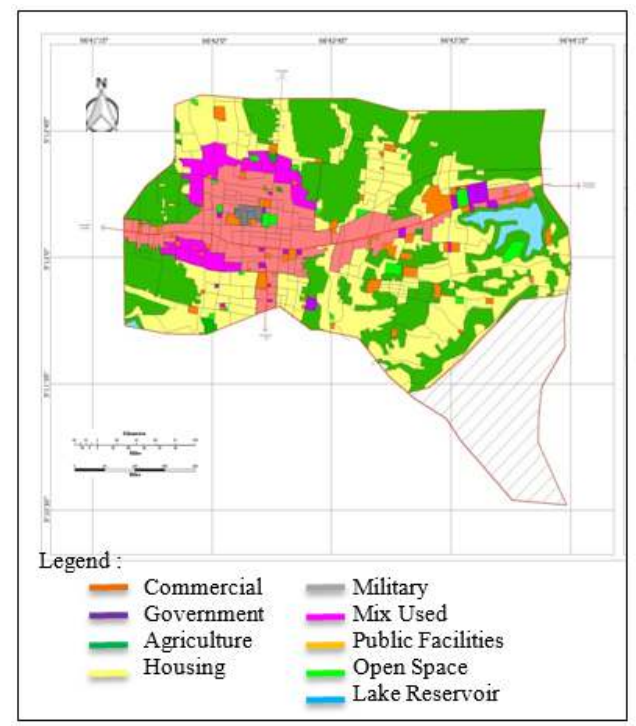

Fig. 4. Land-use Kota juang in 2001-2017

The changes that occur are natural in a new developing city, In figure 5 agriculturer reduced the agricultural area reduced, housing continues to increasees, from the picture can seen the green creases in yellow, commercial starts to develop spread in the direction of the arteri road ways. Comparison of changes in the use of struggle for agricultural land before the expansion of urban areas. There are two periods, before and after urban expansion (figure 5).

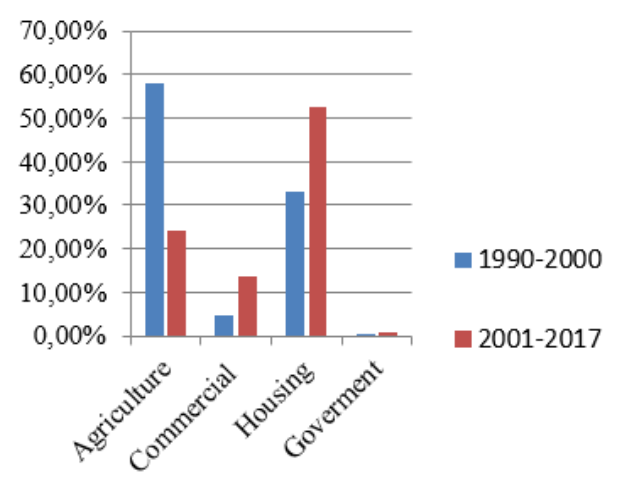

Fig. 5. Comparation urban land-use Kota Juang

\subsection{Topography Factor}

The condition topography Kota Juang flat and wavy $0-8 \%$ with maximum hight above sea level at $197 \mathrm{~m}$ a.s.l (figure 6). There are four types of topographic heights at $181.5 \mathrm{~m}$ a.s.l agricultre area is land-use dominant, $186.7 \mathrm{~m}$ a.s.l are area of housing, commercial, government and mix-use area, $193 \mathrm{~m}$ a.s.l are housing and agriculture, are $197 \mathrm{~m}$ a.s.l housing, agriculture, and commercials in figure 7. 


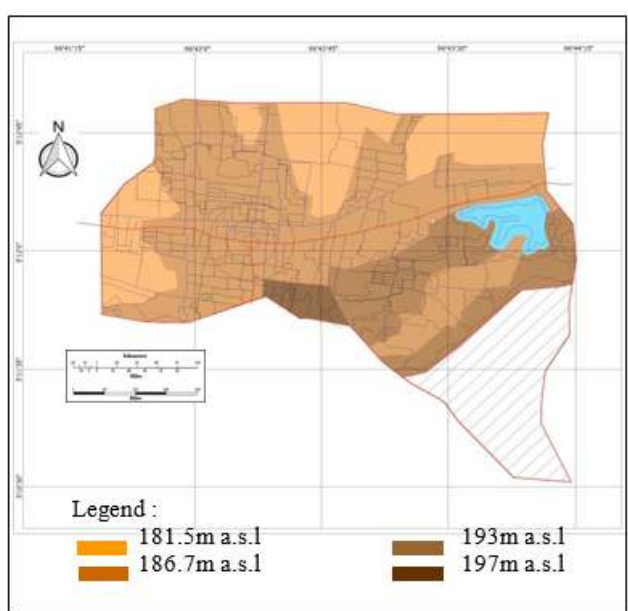

Fig. 6. topography contour of Kota Juang, Bireuen

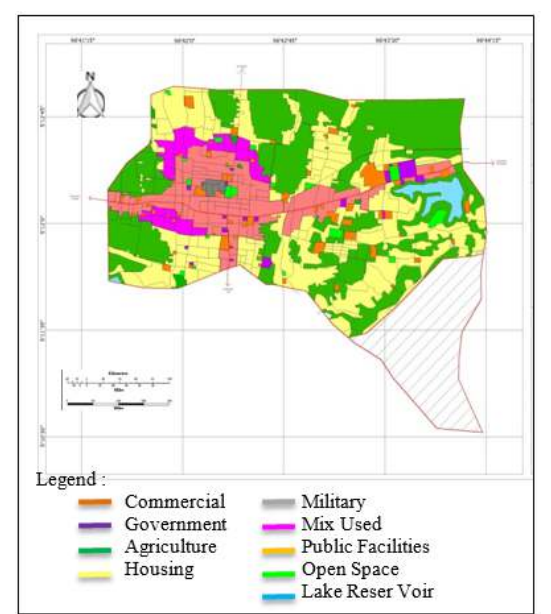

Figure 7: land-use Kota Juang, Bireuen based on topography

Futhermore, good topography that is widely used by users at $186.7 \mathrm{~m}$ a.s.l caused wide plain, however at $181.5 \mathrm{~m}$ s.a.l start to change aggiculture to housing and residential area.

\subsection{Accessibility Factor}

Accessibility determine ideal or not access to public facilities in Kota Juang, Bireuen. The distribution of public facilities to be achieved spread in the center Kota Juang, Bireuen includes the achievement of several public service facilities, namely health facilities such as hospitals, health center,and clinik in position close access with commercial area and military area. Acording analysisacces to hospital very aeasy with good road collector without traffic jam, while health center Kota Juang located in housing land-use, it mean very easy to access because located directly in same area (Figure 7 and Table 1).

The Transportation facilities that bus station located in commercial land-use, it is very profitable to archive commercial area, while gas station located close in government, housing and education area.

Public service facilities for open green space are only $0.75 \%$ of wide Kota Juang, but acces this place very easy to access located in commercial area, then stadium football located in housing and goverment area at arteri road ways.

Public facilities of worship Masjid Agung Sultan Bireuen located in commercial and housing area with distance access very easy in arteri road, facilities education such as primary school scattered in every village but midle school and high school located center in one area at artery road (figure 8 and Table 1). 


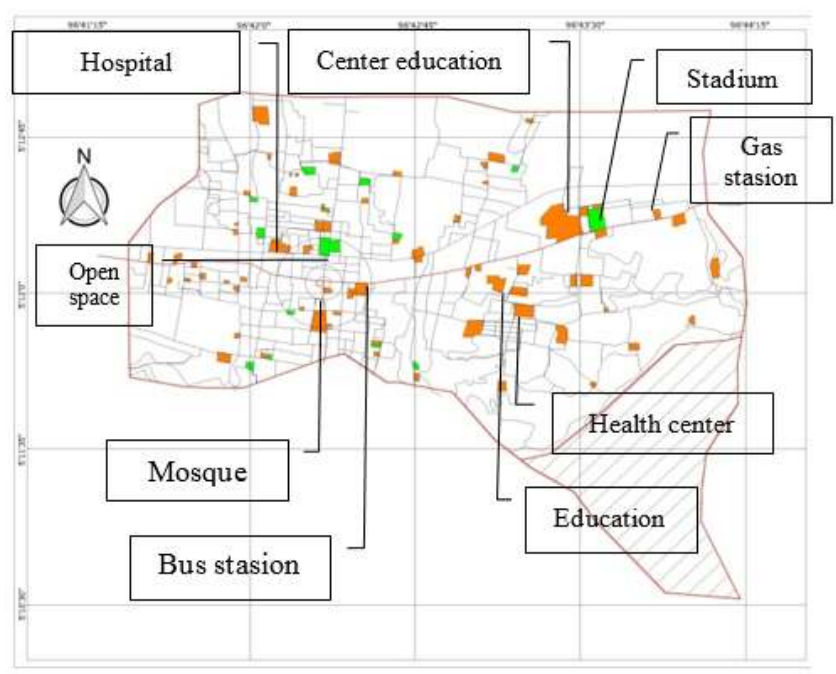

Fig. 8. Accesibility to public facilities Kota juang

Disribution public facilities Kota Juang so it is very easy to reach from the Kota Juang and regional scale of the Bireuen regency.

Table 1. Distribution Public Facilities

\begin{tabular}{cccc}
\hline Facility & $\begin{array}{c}\text { Amount } \\
\text { unit }\end{array}$ & Located in area & Distance accecibility \\
\hline Hospital & 4 & Commercial and millitary area & $1 \mathrm{~km} /$ Easy acces \\
$\begin{array}{c}\text { Health center } \\
\text { clinic }\end{array}$ & 2 & Residential area & $2 \mathrm{~km} /$ Easy acces \\
Education & 19 & Residential area & $1.5 \mathrm{~km} /$ Easy acces \\
SD/SMP/SMA & 37 & Govenrment, commercial and & $1 \mathrm{~km} /$ Easy acces \\
Uneversity & 1 & Residential area & $2.5 \mathrm{~km} /$ Easy acces \\
Mosque & 30 & Commercial and Residential area & $1 \mathrm{~km} /$ Easy acces Easy \\
Bus Station & 1 & Commercial & $1 \mathrm{~km} /$ Easy acces \\
Gas station & 2 & Govenrment, commercial and & $800 \mathrm{~m} /$ Easy acces \\
\hline
\end{tabular}

Since a long time ago it was a trade transportation link to Takengon, Aceh Tengah Regency. Produce from Takengon such as coffee and vegetables transit in Kota Juang Bireuen and transported to market Banda Aceh and Medan, and caused transportation to takengon was mountain road conditions also traders waiting in Kota Juang, Bireuen for pick up after being taken down from Takengon. so directly the city of Kota Juang Bireuen important role for the economic Aceh region, with the advantage of the three lane golden triangle economies of Aceh [9]Detail map of regional accessibility in Figure 9. 


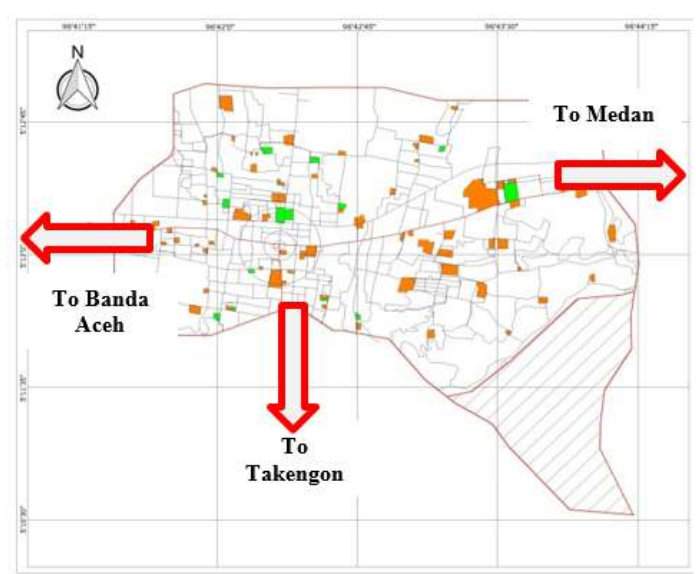

Fig. 9. Regional accessibility of Kota juang

\subsection{Human growth factor}

The factors of human growth is birt increase population in kota Juang occurs because influece migration entering and high birt rates ratio comparated to death rates. The increase of urban population growth in Kota Juang is caused by econimic value in center city to tradeand other benefical interests as evidenced by changes in land-use, the wider the area is built than the area that is not built

Table 2. Population growth Kota Juang, Bireuen

\begin{tabular}{ccccccc}
\hline $\mathbf{2 0 0 5}$ & $\mathbf{2 0 0 7}$ & $\mathbf{2 0 1 0}$ & $\mathbf{2 0 1 2}$ & $\mathbf{2 0 1 3}$ & $\mathbf{2 0 1 5}$ & $\mathbf{2 0 1 7}$ \\
\hline 41900 & 43399 & 43519 & 46528 & 47419 & 49758 & 50710
\end{tabular}

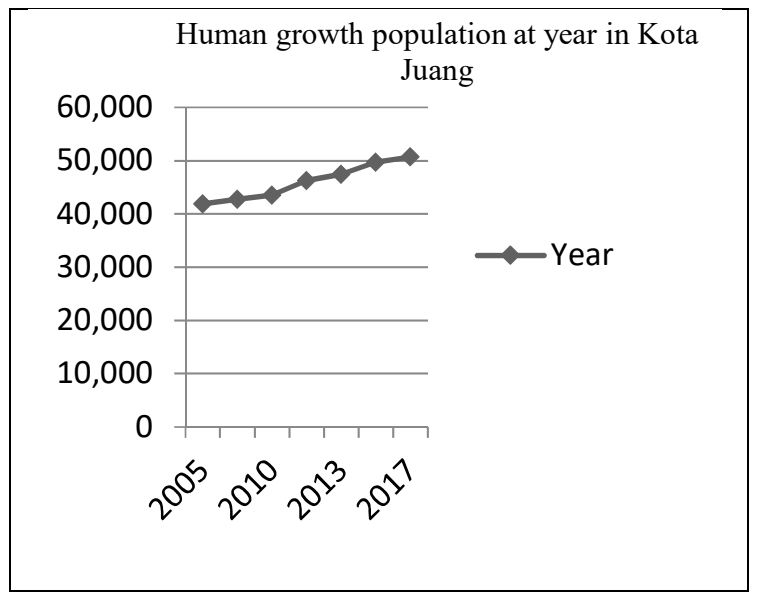

Fig. 10. Increasing population growth in the last 10 years 


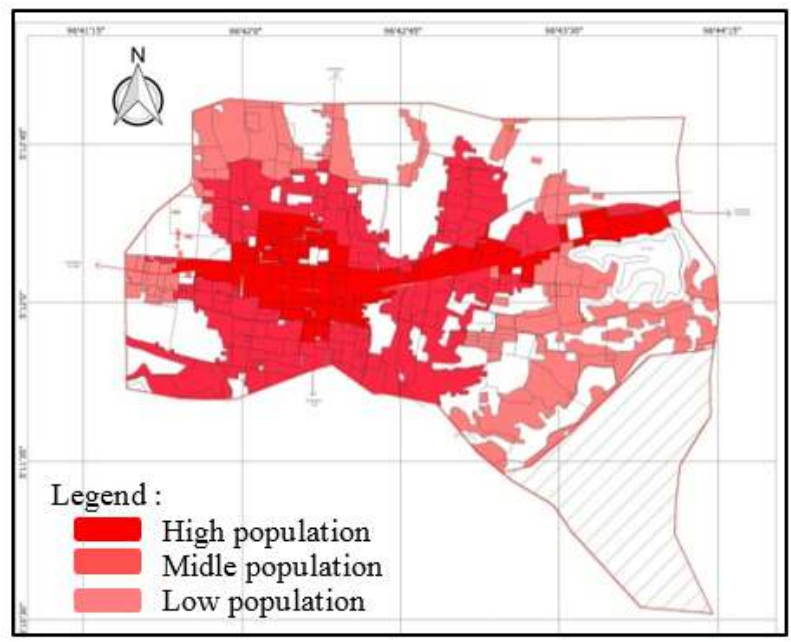

Fig. 11. population Kota Juang

The analysist of population growth from 2005 to 2017 experienced an increase of $21 \%$ (fig.11). Easiness in the community economy has an increase in the migration population, because coming to Kota Juang, Bireuen is moore profitable. Acording BPS Bireuen in 2016 birt rate 459 people and death 204 with migration on 2016 1are 451 people.

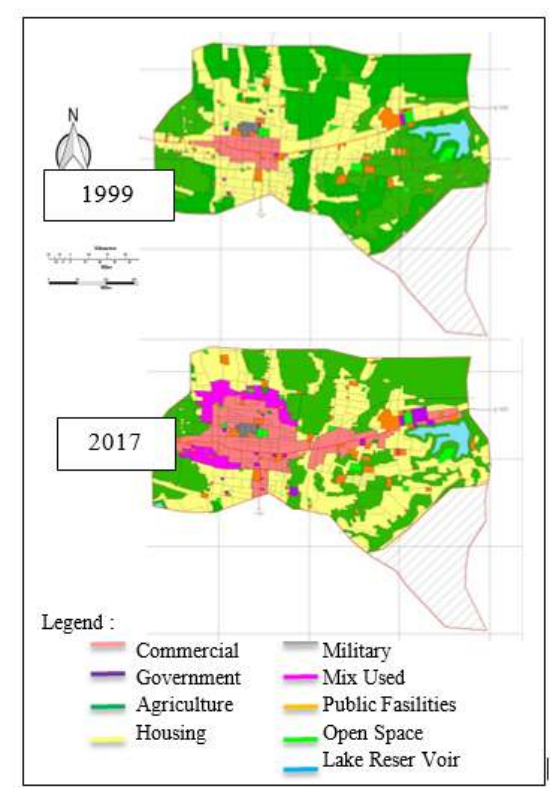

Fig. 12. Land-use based on Population influence in 1999 and 2017

Influence of population growth on Kota Juang affected economic activity in core city, there is change land-use housing to commercial and housing to mix used (figure. 12). 


\section{Conclusion}

Four factors namely urban expansion, topography accesibility, and human growth imfluence to change, acording analysist finding urban expansion and human growth is the most factor change uraban land-use land-use Kota Juang, Bireuen. Recommendation to Bireuen government has need to plan new area in other sub-distrik develop agriculture caused in Kota Juang agriculture decreasing and control management related urban land-use change. This study can benefit the community, developers and others in the industry to obtain information on the land-use changes that occur in Kota Juang, Bireuen. The findings can also be used by the government in evaluating the spatial plans in Kota Juang, Bireuen..

\section{References}

[1] T. Firman, "The continuity and change in mega-urbanization in Indonesia: A survey of JakartaBandung Region (JBR) development," Habitat Int., vol. 33, pp. 327-339, 2009.

[2] A. Yusran, "Kajian Perubahan Tata Guna Lahan Pada Pusat Kota Cilegon," Publ. Tesis Univ. Diponogoro, 2006.

[3] N. and W. P. Puspitasari, "Faktor yang Mempengaruhi Perubahan Guna Lahan dan Pola Perkembangan Permukiman Kawasan Pinggiran (Studi Kasus: Daerah Gedawang, Kota Semarang)," J. Tek. Perenc. Wil. Kota, vol. 2, no. 3, pp. 638-648, 2013.

[4] N. K. Pontoh, "Hubungan Perubahan Penggunaan Lahan dengan Limpasan Air Permukiman: Studi Kasus Kota Bogor,” J. Reg. City Plan., vol. 16, no. 3, pp. 44-56, 2005.

[5] F. Miro, Perencanaan Transportasi bagi Mahasiswa, Perencana dan Praktisi. Jakarta: Erlangga, 2004.

[6] Priambudi \& Pigawati, "Faktor-Faktor Yang Mempengaruhi Perubahan Pemanfaatan Lahan Dan Sosialekonomi Di Sekitar Apartemen Mutiara Garden,” J. Tek. PWK, vol. 3, no. 4, 2014.

[7] D. Zulkaidi, "Masalah Perluasan Kota," J. Reg. City Plan., vol. 2, no. 1, pp. 19-26, 1991.

[8] L. Moleong, Metodologi Penelitian Kualitatif. Bandung: PT. Remaja Rosdakarya, 2010.

[9] Amna Butt, Rabia Shabbir, Sheikh Saeed Ahmad Neelam Aziz, 2015.Land use change mapping and analysis using Remote Sensing and GIS: A case study of Simly watershed, Islamabad, Pakistan. The Egyptian Journal of Remote Sensing and Space Sciences. 